\title{
ANALISIS POTENSI EKOWISATA HEART OF BORNEO DI TAMAN NASIONAL BETUNG KERIHUN DAN DANAU SENTARUM KABUPATEN KAPUAS HULU
}

\author{
Analysis of Ecotourism Potential of Heart of Borneo in Betung Kerihun and Danau Sentarum \\ National Parks, Kapuas Hulu District
}

\author{
Erni Yuniartia ${ }^{\mathrm{a}}$, Rinekso Soekmadi ${ }^{\mathrm{b}}$, Hadi Susilo Arifin ${ }^{\mathrm{c}}$, Bambang Pramudya Noorachmat $^{\mathrm{d}}$ \\ ${ }^{a}$ Program Pascasarjana Pengelolaan Sumber Daya Alam dan Lingkungan, Institut Pertanian Bogor, Kampus IPB \\ Darmaga, Bogor 16680 -erniyuniarti1978@gmail.com \\ ${ }^{b}$ Departemen Konservasi Sumberdaya Hutan dan Ekowisata, Fakultas Kehutanan, Kampus IPB Darmaga, Bogor \\ 16680 \\ ${ }^{c}$ Departemen Arsitektur Lanskap, Fakultas Pertanian, Institut Pertanian Bogor, Kampus IPB Darmaga, Bogor 16680 \\ ${ }^{d}$ Departemen Teknik Mesin dan Biosistem, Fakultas Teknologi Pertanian, Institut Pertanian Bogor, Kampus IPB \\ Darmaga, Bogor 16680
}

\begin{abstract}
Betung Kerihun National Park (TNBK) and Danau Sentarum National Park (TNDS) is one of the Conservation District that directly adjacent to neighboring Malaysia and as a form of Transboundary Conservation Area (TBCA) between Indonesia and Malaysia. This national park is also included in the National Tourism Strategic Area (KSPN) and becomes one of the three Destination Management Organization of the Ministry of Tourism of the Republic of Indonesia as well as the National Tourism Destination. Tourism sector, particularly ecotourism can be used as the spearhead and even become a leading sector in increasing the potential of PAD. This study aims to analyze the tourism potential and attractions of attraction in two national parks and determine the feasibility in ecotourism development. This research was using descriptive research, with approach using analysis of tourism potency and object of natural tourist attraction (Obyek Daya Tarik Wisata Alam/ODTWA). The results show that TNBK and TNDS is feasible to be developed as ecotourism destination based on the recapitulation of potential value of objects and natural attractions attraction with a potential value index of $78.20 \%$. Some criteria that require attention and improvement are accessibility and accommodation, so it can be a priority if this national park area developed into ecotourism destination.
\end{abstract}

Keywords: Heart of Borneo, national park, potential ecotourism

(Diterima: 23-10-2017; Disetujui: 03-01-2018)

\section{Pendahuluan}

Kawasan hutan Heart of Borneo atau Jantung Borneo adalah salah satu kawasan yang memiliki keanekaragaman hayati terkaya di dunia dan merupakan suatu kawasan di wilayah perbatasan Indonesia-Malaysia di Kalimantan serta mencakup sebagian wilayah Brunei Darussalam yang telah disepakati bersama antara ketiga negara tersebut untuk dikelola berdasarkan prinsip-prinsip konservasi dan pembangunan berkelanjutan (conservation and sustainable development). Kabupaten Kapuas Hulu memiliki dua taman nasional yaitu Taman Nasional Betung Kerihun (TNBK) dan Taman Nasional Danau Sentarum (TNDS). Keberadaan Taman Nasional di Kabupaten Kapuas Hulu merupakan suatu kebanggaan karena merupakan aset nasional bahkan internasional yang memberikan kontribusi manfaat jasa lingkungan yang besar baik secara lokal maupun global, sehingga keberadaannya dapat dilestarikan (BAPPEDA, 2015). Berdasarkan Peraturan Presiden No. 3 Tahun 2012 ditetapkan sebagai pusat pengembangan ekowisata dan wisata budaya dan sangat potensial untuk dikembangkan sebagai obyek ekowisata. Dengan memiliki keunikan masing-masing, kawasan Taman
Nasional ini merupakan kawasan pelestarian alam yang memiliki peran penting dalam menjaga keseimbangan sumber daya alam dan harus bersinergi, sehingga dalam pengelolaannya harus mempertimbangkan kebijakankebijakan yang ada (BTNDS, 2015). Potensi ini dapat menjadi andalan untuk digali dan dikembangkan sehingga dapat memberikan sumbangan bagi pendapatan daerah dan memberikan manfat bagi kesejahteraan masyarakat.

Kekayaan alam dan budaya di Kabupaten Kapuas Hulu belum dikembangkan secara baik dan menjadi andalan pariwisata alam dan budaya karena belum tergarap secara optimal, sehingga belum menjadi tujuan primadona bagi para wisatawan. Faktor-faktor penghambat tersebut antara lain: banyaknya obyek daya tarik ekowisata yang belum dikelola dan ditata secara profesional, akses jalan ke obyek wisata relatif belum memadai, infrastruktur, peran serta dan kesadaran masyarakat masih relatif rendah. (Disbudpar $\mathrm{KH}, 2014)$.

Salah satu pengelolaan hutan yang diyakini dapat memberikan manfaat ekonomi, budaya dan sosial secara berkelanjutan adalah pengembangan ekowisata. Ekowisata tidak hanya mendorong pertumbuhan ekonomi secara regional maupun lokal untuk 
meningkatkan kesejahteraan masyarakat, namun juga memelihara kelestarian sumber daya alam, dalam hal ini keanekaragaman hayati sebagai daya tarik wisata Ekowisata dapat membawa dampak positif berupa peningkatan ekonomi, konservasi, pelestarian lingkungan, dan pemberdayaan masyarakat lokal (Rahzen, 2000; Beaumont, 2011; Hoyman dan McCall, 2013; Shoo dan Songorwa, 2013).

Sebagai Kabupaten yang memiliki 2 taman nasional, potensi-potensi yang potensial, keanekaragaman hayati dan termasuk dalam kawasan perbatasan Negara dan provinsi, Kabupaten ini sangat layak untuk dijadikan destinasi ekowisata unggulan. Batasan ekowisata meliputi: pengembangan dan penyelenggaraan kegiatan berbasis pemanfaatan lingkungan untuk perlindungan, partisipasi aktif masyarakat, pendidikan dan pembelajaran, berdampak negatif minimum, memberikan kontribusi positif (Sekartjakrarini dan Legoh, 2004) dan sebagai wisata yang dikelola dengan pendekatan konservasi (Fandeli, 2000). Sebagai kawasan konservasi, ekowisata merupakan salah satu bentuk kegiatan yang dapat dilaksanakan di dalam kawasan ini.
Berdasarkan uraian diatas, hal tersebut merupakan dasar pemikiran pentingnya penelitian ini dilakukan dengan menilai potensi-potensi yang tersedia di kawasan TNBK dan TNDS untuk mengetahui kelayakannya sebagai daerah tujuan ekowisata. Penelitian ini bertujuan untuk menganalisis potensi obyek dan daya tarik wisata alam di kawasan TNBK dan TNDS Kabupaten Kapuas Hulu.

\section{Metode Penelitian}

\subsection{Waktu dan Lokasi Penelitian}

Penelitian dilakukan bulan Januari sampai bulan Juni 2016. Lokasi penelitian berada di Taman Nasional Betung Kerihun (TNBK) Seksi Pengelolaan Taman Nasional (SPTN) I Lanjak Bidang PTN Wilayah I Mataso dan Taman Nasional Danau Sentarum SPTN Wilayah II Semitau Kabupaten Kapuas Hulu Provinsi Kalimantan Barat.

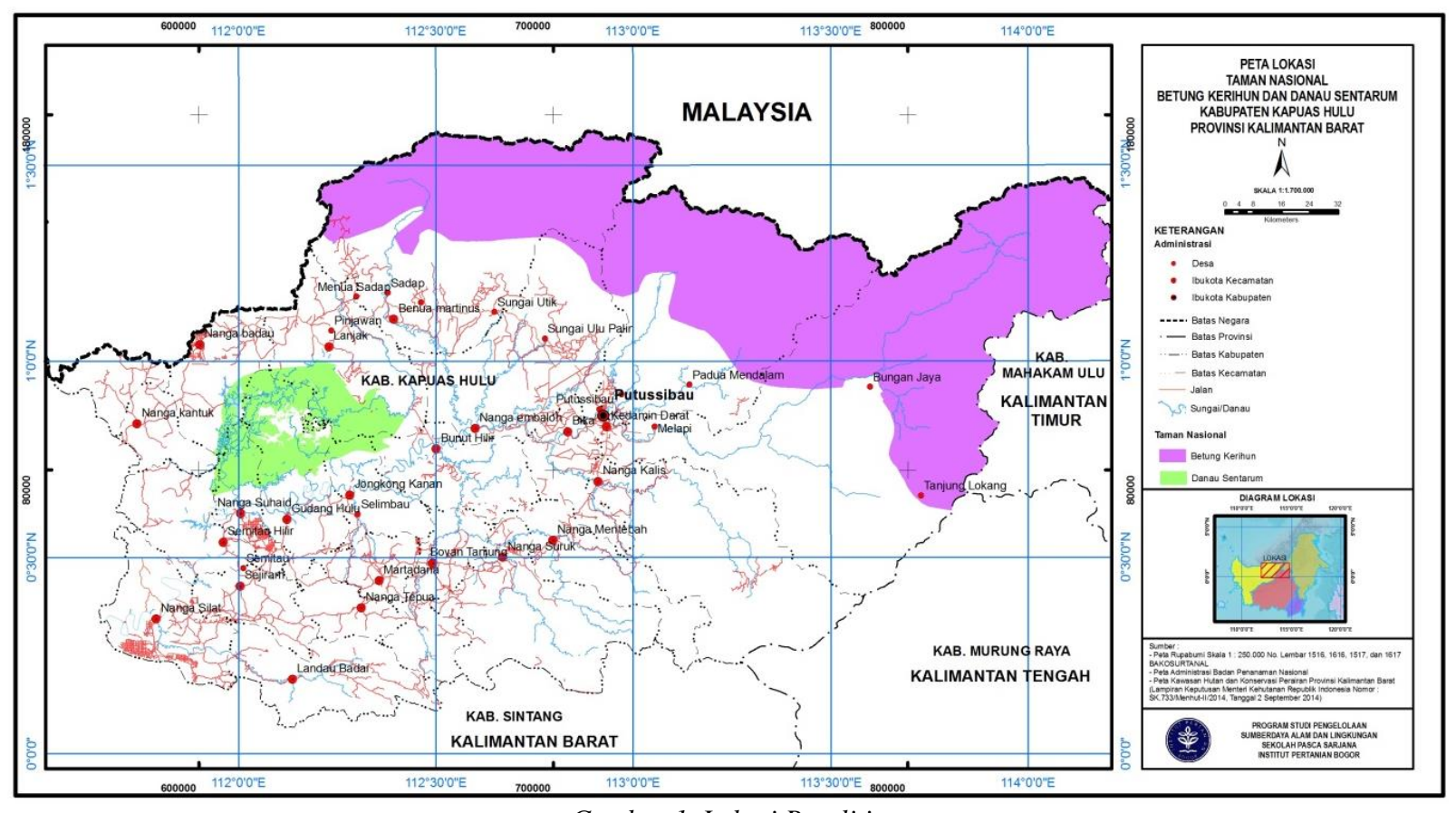

Gambar 1. Lokasi Penelitian

\subsection{Matriks Pengumpulan Data dan Analisis Data}

Matriks pengumpulan data dan analisis data meliputi variabel yang diukur, teknik pengumpulan data, teknik analisis data dan output yang diharapkan dalam penelitian (Tabel 1).

\subsection{Metode Analisis}

Analisis penilaian potensi ekowisata di taman nasional ini dilakukan dengan cara penilaian obyek dan daya tarik wisata alam yang menggunakan sistem skor dan pembobotan berdasarkan Pedoman Analisis Operasi dan Obyek Daya Tarik Wisata Alam (ADO-
ODTWA) yang ditetapkan oleh Direktorat Wisata Alam dan Pemanfaatan Jasa Lingkungan, Dirjen Perlindungan Hutan dan Konservasi Alam tahun 2003. Penilaian dilakukan untuk mendapatkan bobot dari penilaian setiap unsur terhadap setiap obyek wisata berdasarkan 9 kriteria penilaian (tabel 1) Penilaian dilakukan sebagai upaya suatu daerah dalam mengembangkan daerah tujuan wisatanya dan memberikan justifikasi kelayakan suatu kawasan yang layak dikembangkan. Hasil pengolahan data mengenai obyek dan daya tarik alam diuraikan secara deskriptif. Jumlah skor/nilai untuk satu kriteria penilaian ODTWA dapat dihitung dengan persamaan sebagai berikut (Persamaan 1): 
$\mathrm{S}=\mathrm{N} \times \mathrm{B}$

Keterangan :

$\mathrm{S}=$ skor/nilai suatu kriteria

$\mathrm{N}=$ jumlah nilai unsur-unsur pada kriteria

$\mathrm{B}=$ bobot nilai

Setelah dilakukan perbandingan, maka akan diperoleh indeks kelayakan dalam persen. Indeks kelayakan suatu kawasan ekowisata adalah sebagai berikut (Karsudi et al., 2010):

1. Tingkat kelayakan $>66.6 \%$ : Kawasan yang layak dikembangkan

2. Tingkat kelayakan $33.3 \%$ - 66.6\%: Kawasan belum layak dikembangkan

3. Tingkat kelayakan < 33.3\%: Kawasan tidak layak dikembangkan

Tabel 1. Variabel yang diukur, teknik pengumpulan data, teknik analisis data dan output yang diharapkan

\begin{tabular}{|c|c|c|c|}
\hline Variabel yang diukur & Teknik Pengumpulan Data & Teknik Analisis Data & Output yang diharapkan \\
\hline $\begin{array}{l}\text { 1. Daya Tarik ODTWA } \\
\text { 2. Kadar hubungan/aksesibilitas } \\
\text { 3. Kondisi lingkungan sosial } \\
\text { ekonomi sekitar kawasan } \\
\text { 4. Pengelolaan dan pelayanan } \\
\text { 5. Akomodasi } \\
\text { 6. Sarana dan prasarana penunjang } \\
\text { 7. Ketersediaan air bersih } \\
\text { 8. Hubungan dengan obyek wisata } \\
\text { di sekitarnya } \\
\text { 9. Keamanan }\end{array}$ & $\begin{array}{l}\text { Pengamatan dan menghitung potensi, } \\
\text { obyek dan daya tarik } \begin{array}{r}\text { wisata } \\
\text { berdasarkan panduan }\end{array} \text { ODTWA dari } \\
\text { DJPHKA (2003) }\end{array}$ & $\begin{array}{l}\qquad \mathbf{S}=\mathbf{N} \times \mathbf{B} \\
\text { Keterangan: } \\
\mathrm{S}=\text { skor/nilai suatu kriteria } \\
\mathrm{N}=\text { jumlah nilai unsur- } \\
\text { unsur pada kriteria } \\
\mathrm{B}=\text { bobot nilai }\end{array}$ & $\begin{array}{l}\text { Kelayakan ODTWA } \\
\text { dalam pengembangan } \\
\text { ekowisata }\end{array}$ \\
\hline
\end{tabular}

\section{Hasil dan Pembahasan}

\subsection{Penilaian Obyek dan daya Tarik Wisata Alam}

Obyek dan Daya Tarik Wisata merupakan potensi yang menjadi pendorong kehadiran wisatawan ke suatu daerah tujuan wisata (Suwantoro, 2004), dimana TNBK dan TNDS merupakan kawasan konservasi yang memiliki keanekaragaman hayati dan pesona keindahan alam. Ekowisata tidak hanya diyakini dapat mendorong pertumbuhan ekonomi secara regional maupun lokal untuk peningkatan kesejahteraan masyarakat, namun juga kelestarian sumberdaya alam dan keanekaragaman hayati sebagai obyek dan daya tarik wisata (Purwanto et al., 2014). Ada lima unsur yang dinilai dari obyek daya tarik wisata alam di kawasan ini dan nilai untuk daya tarik dan wisata alam adalah 840 (Tabel 1). Nilai tersebut menggambarkan bahwa kawasan ini sangat berpotensi dan layak untuk dikembangkan sebagai kawasan ekowisata.

Potensi atau daya tarik yang khas sangat menentukan tingkat kunjungan pada kawasan tertentu. Selain terkenal dengan keunikannya, kawasan ini juga memiliki sumberdaya alam yang menonjol, seperti batuan, flora fauna dan gejala alam (air terjun, tebing) yang mengandung nilai yang tinggi. Hasil penelitian (Lochana et al., 2011) menyatakan bahwa banyaknya jenis kegiatan ekowisata mulai dari jungle tracking, bird watching, kegiatan wisata alam dengan tujuan pendakian, camping ground, pendidikan, fishing dan canoeing.

\subsection{Daya Tarik Biologi}

Kawasan taman nasional ini memiliki berbagai macam ekosistem. Ada 5 tipe ekosistem di lokasi embaloh dikawasan TNBK yaitu: Hutan Alluvial, Hutan Dipterocarpaceae, Hutan Dipterocarpaceae, Hutan Sub Gunung, dan Hutan Gunung (BBTNBK, 2015). Sedangkan tipe ekosistem di Bukit Tekenang umumnya hampir sama di seluruh kawasan TNDS, yaitu (BTNDS, 2015a): Hutan rapak gelagah (hutan rawa kerdil), Hutan Gelagah (Hutan Rawa Terhalang), Hutan Pepah (Hutan Rawa Tegakan), Hutan Tepian (Hutan Riparian), Hutan Rawa Gambut terdapat pada daerah yang agak tinggi, Hutan Dataran Rendah Perbukitan.

Berdasarkan database flora di kawasan TNBK terdapat 1,216 jenis flora yang telah diidentifikasi termasuk dalam 418 marga dan 110 suku. Didalamnya terdapat 75 jenis yang endemik Borneo, dan sebanyak 14 jenis merupakan catatan baru. Sedangkan potensi flora di lokasi Embaloh sekitar 83 jenis tumbuhan yang sudah teridentifikasi, dan sebagian yang sedang dalam proses identifikasi untuk penentuan jenis. Kawasan di TNDS memiliki kurang lebih 794 jenis pohon dan perdu jenis anggrek (2.9\% dari 27500 jenis tumbuhan berbunga di Indonesia) (BBTNBK, 2015)

Secara umum potensi fauna di kawasan TNBK adalah Mamalia 48 jenis, Primata 17 jenis, Burung 301 jenis, herpetofauna 103 jenis, ikan 112 jenis dan serangga 170 jenis. Sementara penyebaran satwa di wilayah Sub DAS Embaloh, baru bisa diidentifikasi sebanyak 37 jenis burung, 15 jenis mamalia dan 22 jenis kupu-kupu yang dilakukan pihak TNBK bekerjasama dengan Institut Pertanian Bogor tahun 2015. Proses kegiatan pemutakhiran database flora ini sampai sekarang masih terus berjalan dan beberapa specimen flora masih terus dilakukan identifikasi di museum Bogor (BBTNBK, 2015). Potensi fauna di TNDS terdiri dari 147 jenis mamalia $(28.5 \%$ dari 515 jenis mamalia Indonesia atau 2/3 (64\%) mamalia di Kalimantan dapat ditemukan di kawasan Danau Sentarum dan 32 jenis diantaranya merupakan jenis yang dilindungi, 67 jenis reptilia (13.1\% dari 511 jenis reptilia Indonesia) dan 16 jenis diantaranya dilindungi, 22 jenis (8.2\% dari 270 dari amphibia Indonesia), 311 jenis burung (20.3\% dari 1531 jenis burung Indonesia) dan 68 jenis diantaranya merupakan jenis yang dilindungi, serta 266 jenis ikan (19\% dari 1400 jenis 
ikan air laut dan air tawar di Indonesia) dan dari jumlah jenis tersebut 3 jenis diantaranya merupakan jenis yang dilindungi, serta 13 jenis diantaranya merupakan jenis baru (new species) yang ditemukan di dunia (BTNDS, 2015a).

\subsection{Daya Tarik Fisik}

\section{a. Penyusuran Sungai dan Karangan}

Penyusuran sungai menggunakan perahu di DAS Embaloh dapat dilakukan sepanjang perjalanan menuju kawasan yaitu melewati sungai Tekelan, sungai Santu', sungai Pait dan sungai Embaloh. Menjelajahi sungai yang jernih dengan menggunakan perahu merupakan kombinasi menarik untuk kegiatan ekowisata.

Sungai Santu' merupakan anak Sungai Tekelan yang mempunyai hamparan yang cukup luas dan relatif datar. Di bagian hulu Sungai Pait terdapat 2 air terjun, yaitu air terjun Condong dengan tinggi 25 meter namun airnya tidak langsung terjun, melainkan jatuh menempel di permukaan batu sehingga membentuk ukiran-ukiran dibatu dan air terjun Sungai Pait dimana tingginya lebih dari 7 meter dengan air yang langsung jatuh. Pada bagian bawahnya terdapat telaga yang cukup luas untuk mandi.

Bentuk Sungai Embaloh lebih lebar dari Sungai Tekelan dan batu-batu masifnya tidak terlalu dominan. Kondisi vegetasi di pinggir sungai cukup rapat dengan kanopi yang saling bertemu pada beberapa lokasi. Semakin ke hulu terdapat beberapa air terjun kecil di pinggir Sungai Embaloh dan semakin menambah keseruan penjelajahan sungai ini. Satwa-satwa yang sering terlihat di pinggiran sungai adalah burung raja udang, burung elang, bahkan kelompok enggang yang terbang di atas ketinggian. kelompok primata monyet ekor panjang dan kelasi juga bisa dijumpai dalam perjalanan ini. Pada salah satu anak sungai Embaloh, yaitu tepatnya di Sungai Dajoh terdapat potensi air terjun yang menjadi salah satu destinasi wisata di Sub DAS Embaloh ini.

\section{b. Pendakian Gunung Betung}

Pendakian Gunung Betung dengan ketinggian 1,150 $\mathrm{m}$ dapat di capai dengan waktu 2 hari dimulai dari Dusun Sadap dan menjadi sensasi tersendiri karena merupakan salah satu simbol Taman Nasional Betung Kerihun. Berbagai variasi pemandangan seperti ekosistem Hutan Dipterocarpacae Dataran Rendah, Dipterocarpacae Bukit, Hutan Sub Gunung hingga Hutan Gunung dapat disaksikan dalam pendakian ini. Jenis satwa seperti Kelampiau (Hylobathes muellerii), Babi Hutan (Sus barbatus), Monyet Ekor Panjang (Macaca fascicularis), tupai, burung-burung bisa saja dijumpai di perjalanan pendakian Gunung Betung karena memang lokasi merupakan bagian dari habitat satwa tersebut

\section{c. Rumah Pohon}

Rumah pohon ini baru didirikan satu buah yang telah dibangun pihak TNBK, terdapat di pinggir sungai Embaloh di atas pohon Kensurai (Dipterocapus oblongifolius. Wisatawan dapat menginap dan merasakan sensasi tinggal di atas kanopi pohon sambil mengamati satwa terutama burung, serta primata yang memang banyak penyebarannya disekitar kawasan. Hanya saja rumah pohon ini harus terus dipantau dikarenakan kondisi ketika ke lokasi barang-barang yang terdapat di rumah pohon sudah tidak ada. Adanya oknum yang tidak bertanggungjawab yang mengambil perlengkapan di dalam rumah pohon. Hal ini dapat mempengaruhi kenyamanan dan keamanan wisatawan. Sebelah kiri dari rumah pohon ini terdapat jalur interpretasi yang telah di buat dalam rangka pengembangan ekowisata.

\section{d. Gua Pajau}

Gua pajau ini tidak terlalu besar, namun sering dijadikan tempat berlindung sementara hewan seperti pelanduk/kancil, kijang, rusa dan juga ular. Ini dapat diketahui dari bekas jejak, bulu-bulu serta bekas kulit ular yang terdapat di lantai gua. Dari mulut gua, dapat dilihat pemandangan bentang alam yang indah serta tajuk-tajuk pohon yang tampak lebih rendah. Untuk mencapai Gua Pajau ini dapat ditempuh dengan mendaki sebuah puncak bukit kecil selama 1 (satu) jam perjalanan dimulai dari Riam Naris.

\section{e. Bukit Tekenang}

Kawasan Danau Sentarum memiliki unggulan daya tarik lansekap, biologi dan budaya menjadikan kawasan taman nasional ini memiliki nilai strategis yang tinggi. Potensi wisata alam ini berupa bentangan alam dari hamparan danau yang luas yang diselingi oleh kelompok-kelompok vegetasi. Salah satu obyeknya di dalam kawasan ini adalah Bukit Tekenang, yang merupakan salah satu bukit sebagaimana layaknya sebuah pulau yang muncul begitu saja di atas hamparan perairan danau. Kawasan Bukit Tekenang merupakan salah satu bukit yang terletak di tengah danau kawasan Danau Sentarum.

Bukit ini mempunyai ketinggian sekitar 130 meter dari permukaan laut sehingga sangat ideal untuk jalur pendakian dan diperlukan waktu 20-25 menit untuk mencapai puncak. Di atas bukit bisa melihat landscape danau sentarum dan tempat ini merupakan lokasi paling favorit untuk mengambil gambar pemandangan Danau Sentarum dari atas. Dari atas Bukit Tekenang, wisatawan bisa melihat gua kelelawar dan di sepanjang jalur pendakian terdengar berbagai macam suara burung, sehingga lokasi ini juga sangat ideal untuk kegiatan mengamati burung (bird watching), terutama burung enggang, king fisher, elang dan lain-lain. Wisatawan juga bisa berenang di danau dan memancing ikan serta melihat aktivitas masyarakat nelayan yang bermukim di sekitar kaki bukit ketika menangkap ikan. 


\subsection{Daya Tarik Sosial Budaya}

Masyarakat yang bermukim di sekitar kawasan yang lebih sering disebut sebagai daerah penyangga, pada umumnya adalah suku Dayak. Masyarakat dayak masih memegang teguh kepercayaan animismenya, mereka percaya setiap tempat-tempat tertentu ada penguasanya, yang mereka sebut Jubata, Petara, Ala Taala, Penompa dan lain-lain, untuk sebutan Tuhan yang tertinggi. Kemudian mereka masih mempunyai penguasa lain di bawah kekuasaan Tuhan tertingginya, misalnya Puyang Gana (Dayak Mualang) adalah penguasa tanah, Raja Juata (penguasa air), Kama Baba (penguasa darat) (BAPPEDA, 2010). Bagi mereka yang masih memegang teguh kepercayaan dinamisme dan budaya aslinya, mereka memisahkan diri masuk semakin jauh ke pedalaman.

Suku Dayak tinggal dirumah yang disebut dengan rumah betang yang menjadi tempat tinggal komunitas setiap suku dengan memperlihatkan kerukunan, kepolosan dan keramah tamahan suku. Rumah Panjang (Betang) yang dihuni oleh suku tersebut beragam besarnya, ada yang dihuni lima sampai delapan kepala keluarga dan ada yang dihuni 15 sampai 30 kepala keluarga. Rumah panjang yang dihuni 15-30 kepala keluarga, mempunyai panjang rata-rata 186 meter dan lebar 6 meter.

Saat ini rumah betang masih dapat dikunjungi dan menjadi salah satu obyek wisata yang diminati oleh wisatawan. Daya tarik sosial budaya terdiri dari:

\section{a. Kearifan lokal}

Tradisi berladang yang dilakukan masyarakat sekitar sangat menarik mulai dari memilih dan menyiapkan lahan, memutuskan ukuran lahan, menentukan skala produksi menurut kebutuhan keluarga dan tenaga kerja, teknik pemanfaatan sumberdaya manusia dan acara kebathinan yang dihubungkan sebagai langkah dalam penyiapan dan pemanenan.

\section{b. Aktivitas memancing}

Aktivitas memancing di Danau Sentarum merupakan daya tarik dapat diberi kesempatan untuk memancing di kawasan yang sudah ditentukan. Wisatawan melakukan aktivitas memancing ikan menggunakan sampan.

\section{c. Memanen madu secara tradisional}

Memanen madu secara tradisional juga dapat dikategorikan daya tarik sosial budaya. Madu Danau Sentarum telah mendapatkan sertifikat sebagai madu organik pertama di Indonesia dari Biocert. Ini berarti madu dari kawasan Danau Sentarum telah diakui kemurniannya dari campuran bahan kimia dan pengelolaannya yang higenis serta berbasis kelestarian yang ramah lingkungan. Danau Sentarum memiliki potensi madu alam yang sangat besar mencapai 20 - 25 ton per tahun (BTNDS, 2009).

\section{d. Tata cara Ritual}

Tata cara Ritual Berdasarkan suku Iban upacara tradisional yang rutin dilakukan adalah Nike' Benih setiap tanggal 1 Juni yang bersamaan dengan Gawai Dayak Iban di bagian Sarawak, Malaysia. Upacara yang dilakukan ini mempunyai arti sebagai rasa syukur masyarakat kepada Batara (Tuhan Yang Maha Esa) atas hasil panen yang berlimpah dan masyarakat berharap pada musim berikutnya dapat diberikan hasil yang lebih berlimpah.

\section{e. Pengobatan Supranatural Tradisional}

Pengobatan Supranatural Tradisional metode pengobatan yang dilakukan untuk memanggil roh dilakukan dengan musik dan tarian. Upacara penyembuhan ini disebut "Tutu Belian" atau "Singamay Belian", dimana dalam proses penyembuhan ini para dukun dibantu oleh seorang Pesirang yang menceritakan syair dan mempersiapkan saparu (seperti kotak yang terbuat dari kuningan). Prosesi dalam penyembuhan ini dilakukan selama 2-3 hari tergantung jenis penyakit yang diderita.

\section{f. Kerajinan tangan}

Kerajinan tangan pada masyarakat Dayak ini memiliki pola dan corak yang unik dan berbeda disetiap suku. Saat ini kerajinan tangan tenun ataupun anyaman masih dibuat untuk digunakan sehari-hari. Bahan anyaman yang digunakan dalam pembuatan kerajinan tenun: rotan, bambu, bemban (Donax $s p$ ). Jika ada wisatawan yang berkunjung dan ingin membeli, barulah dijual oleh masyarakat. Perlu adanya kesepakatan harga dalam penjualan hasil kerajinan tangan ini, sehingga harga yang dijual tidak terlalu tinggi dari tempat lain.

\subsection{Kadar Hubungan/Aksesibilitas}

Jalan masuk atau pintu masuk utama ke daerah tujuan wisata merupakan akses penting dalam kegiatan wisata. Kegiatan pelayanan wisata merupakan suatu kegiatan yang bertujuan untuk memberikan kemudahan, kenyamanan, atau keselamatan pada wisatawan selama tinggal dan dalam kunjungan di kawasan wisata (Muhammad, 2012). Aksesibilitas merupakan faktor yang mempermudah wisatawan untuk berpergian dari tempat tinggal wisatawan ke lokasi obyek wisata yang akan dikunjunginya. Namun dalam konsep pengembangan ekowisata aksesibilitas yang sulit justru menjadi daya tarik tersendiri bagi suatu obyek. Karena jika kawasan ekowisata bisa diakses dengan mudah maka akan menarik jumlah wisatawan yang tinggi sehingga akan menjadi wisata massal. 
Penilaian terhadap aksesibilitas tergolong sedang dengan nilai 400 (Tabel 2). Namun hal ini tidak berarti bahwa penilaian dengan kategori sedang, tidak memiliki kesiapan pengembangan yang baik, namun aspek - aspek kesiapan pengembangan yang ada harus lebih dikembangkan lagi. Namun untuk aksesibilitas dengan klasifikasi sedang pengembangan yang dilakukan harus lebih daripada yang klasifikasi baik. Aksesibilitas dari Putussibau saat ini kondisi jalan sudah bagus dan beraspal semua, bahkan sebagian besar jembatannya sudah permanen. Sedangkan aksesibilitas masuk kedalam kawasan menggunakan jalur sungai.

Perjalanan dari Pontianak menuju Putussibau menggunakan bus selama \pm 16 jam dan jika menggunakan pesawat dari Pontianak ke Putussibau selama \pm 2 jam. Perjalanan dari Putussibau menuju ke TNBK lokasi Embaloh di Dusun Sadap dapat menggunakan kendaraan darat, baik mobil sewaan ataupun angkutan umum selama 2 jam. Pintu masuk lainnya dapat melalui pintu batas negara Badau-Lubuk Antu menggunakan kendaraan umum atau mobil sewaan selama 3 jam ke dusun tersebut. Waktu tempuh ini sangat bervariatif karena sangat tergantung terhadap kondisi pasang surut air sungai. Sedangkan perjalanan ke TNDS untuk berkunjung ke bukit Tekenang, wisatawan dapat menempuh perjalanan dari Putussibau ke Lanjak menggunakan kendaraan roda empat/ Minibus selama \pm 3 jam. Dari Lanjak ke kawasan Danau Sentarum Bukit Tekenang hanya bisa dilalui dengan kendaraan air dengan menggunakan speedboat atau longboat $40 \mathrm{PK}$ selama \pm 40 menit.

\subsection{Kondisi Lingkungan Sosial Ekonomi Masyarakat Sekitar Kawasan}

Masyarakat sekitar kawasan Betung Kerihun umumnya adalah suku Dayak yang pekerjaannya sebagai petani lahan kering (ladang). Sedangkan masyarakat di Danau Sentarum menangkap dan membudidaya ikan, membudidaya lebah madu hutan dan berladang. Sebagian besar nelayan merupakan nelayan tradisional yang menggunakan armada kecil, sehingga daerah tangkapan ikan yang mereka lakukanpun tidak jauh dari lokasi pemukiman. Hal yang paling penting adalah memberikan sosialisasi mengenai wisata kepada masyarakat secara berkala untuk merubah persepsi masyarakat yang tidak siap menjadi terbuka untuk menerima kunjungan.

Dengan masyarakat sebagai pelaku utama, ekowisata merupakan alternatif ekonomi ramah lingkungan dan ramah adat. Modal ekowisata adalah keindahan dan keaslian bentang alam, keanekaragaman hayati maupun keragaman budaya serta kehidupan masyarakat. Jika perencanaannya berdasarkan keterlibatan, kreativitas dan kemampuan masyarakat setempat, ekowisata bisa jadi sumber ekonomi menjanjikan. Selain itu, arus wisatawan bisa dikelola agar tidak merusak alam dan kehidupan sosial- budaya (Eghenter et al., 2012).
Masyarakat sebagai salah satu unsur penting dibutuhkan keterlibatannya secara langsung dalam penataan kawasan wisata (Untari, 2009). Masyarakat berperan penting tidak hanya dalam pengelolaan tetapi juga berperan penting dalam memberikan kulitas pelayanan bagi wisatawan yang berkunjung ke kawasan. Berdasarkan hasil penelitian (Muhammad, 2012) yang menyatakan bahwa semakin meningkatnya kunjungan wisatawan, maka peranan masyarakat sebagai penerima wisatawan juga mulai diikutsertakan dalam pengembangan kawasan. Masyarakat akan berperan lebih aktif dalam menyediakan sarana seperti akomodasi, cinderamata, serta sarana lainnya sehingga potensi ekonomi masyarakat akan berkembang.

Penilaian terhadap unsur dan sub unsur kondisi sekitar kawasan tergolong tinggi dengan nilai 600 (Tabel 2). Melalui wawancara terhadap masyarakat sekitar kawasan, diketahui bahwa pada umumnya masyarakat sangat mendukung upaya pengembangan ekowisata. Tetapi perlu adanya pelatihan untuk masyarakat sebagai pelaku ekowisata oleh dinas terkait. Pola pikir masyarakat harus diubah sehingga masyarakat menyadari bahwa wisatawan yang berkunjung tidak hanya datang pada hari itu saja tetapi akan berkelanjutan.

Besarnya pengaruh yang harus diberikan dari keterlibatan masyarakat terhadap sektor ekowisata dapat dijadikan contoh dan memberikan pengaruh yang signifikan baik terhadap kesejahteraan masyarakat dan terhadap pengembangan ekowisata (Muganda et al., 2013). Dengan adanya pengembangan ekowisata, dapat memberikan kesempatan kepada masyarakat lokal yang bermukim di sekitar kawasan obyek wisata untuk bisa menjadi pelaku wisata. Keterlibatan masyarakat sangatlah penting karena dapat membantu meningkatkan rasa memiliki dan dapat memupuk rasa memiliki (sense of belonging) didalam masyarakat.

Kesiapan masyarakat dalam mendukung dan berperan aktif pengembangan ekowisata sangat positif, ini dapat dilihat dari wawancara dengan masyarakat yang 100\% mendukung pengembangan kawasan menjadi kawasan ekowisata asalkan ada kejelasan dan pelibatan masyarakat dalam setiap prosesnya. Masyarakat berharap dengan adanya kegiatan ekowisata dapat meningkatkan kesejahteraan masyarakat dengan adanya kedatangan wisatawan.

Masyarakat yang berada di Taman Nasional terlibat langsung dalam membantu terselenggaranya ekowisata dan berperan sebagai dinamisator. Mereka menjadikan rumahnya sebagai tempat tinggal (homestay) dan membantu kebutuhan (porter) para pengunjung yang ingin menikmati keindahan dan keunikan serta menyewakan alat transportasi (longboat). Biaya keseharian pengunjung dapat langsung diberikan kepada masyarakat. Pengunjung juga dapat membeli cinderamata berupa hasil kerajinan masyarakat seperti: kain tenun, anyaman dan ukiran kayu. Namun kesiapan tersebut dapat ditingkatkan dengan pelatihan dan pendidikan, mengingat masih minimnya pengetahuan masyarakat mengenai ekowisata dan masih adanya kecemburuan sosial dalam masyarakat dalam 
pembagian tugas sebagai pemandu wisata ataupun penyedia jasa transportasi.

Berdasarkan hasil wawancara, ada oknum masyarakat yang menetapkan harga lebih mahal padahal dalam kelompok jasa transportasi sudah ada kesepakatan yang disetujui oleh seluruh masyarakat. Perlunya perincian biaya yang jelas sehingga biaya untuk wisatawan yang berkunjung ke dalam kawasan dengan menggunakan jasa masyarakat lokal dapat lebih terinci. Namun sebelum memberdayakan masyarakat lokal dalam ekowisata, perlu adanya sosialisasi tentang konsep ekowisata yang sesuai sekaligus pendampingan terhadap masyarakat lokal.

Dengan memberdayakan masyarakat lokal, akan terwujud partisipasi kerjasama yang lebih baik. Tanpa adanya keterlibatan masyarakat lokal dalam perencanaan akan menghasilkan kegagalan (Ogechi dan Igbojekwe, 2013; Rukti dan Rudiarto, 2014). Hasil penelitian Muganda et al. (2013) menunjukkan bahwa kebijakan mengenai keterlibatan masyarakat sudah tepat, sehingga perlu adanya pengawasan terhadap implementasi di lapangan untuk mendapatkan hasil yang baik dari kebijakan yang ada.

Kegiatan ekowisata memiliki dua sisi bagi kehidupan masyarakat, sebagai peluang ekonomi bagi yang dapat mengakses atau merekayasa sumberdaya untuk terlibat dalam kegiatan wisata, sementara yang tidak mampu mengakses sumber daya atau memanfaatkan peluang akan tetap pada sumber-sumber nafkah lama (Kasmiati et al., 2016). Faktor kunci keberhasilan dalam pengembangan ekowisata adalah adanya dukungan masyarakat di suatu kawasan. Peluang bagi masyarakat lokal yang dapat dilakukan dalam pengembangan ekowisata adalah Jasa penginapan (homestay), jasa transportasi sekaligus sebagai motoris dan juru batu, Jasa pemandu wisata, Atraksi Kesenian, dan Jasa pembuatan dan penjualan kerajinan tangan, Masyarakat mempunyai keahlian dalam membuat anyaman bambu, menenun kain, membuat manik dalam berbagai bentuk sehingga wisatawan dapat dilibatkan dalam pembuatan kerajinan tangan.

\subsection{Pengelolaan dan Pelayanan}

Kondisi pengelolaan dan pelayanan secara keseluruhan saat ini tergolong tinggi berdasarkan unsur dan sub unsur yang dinilai sebesar 280 yaitu pengelolaan, kemampuan berbahasa dan pelayanan wisatawan. Pengelolaan obyek dan pelayanan wisatawan merupakan hal yang perlu terus ditingkatkan, karena berpengaruh langsung dengan kepuasan wisatawan dan pelestarian obyek itu sendiri. Selain itu dalam implementasinya perlu ditunjang oleh tenaga profesional di bidang pariwisata alam, mampu berbahasa dan berkomunikasi dengan baik serta memberi pelayanan terhadap wisatawan.

Pelayanan petugas dan masyarakat terhadap wisatawan maupun orang baru dinilai baik dengan nilai 25 dilihat dari segi keramahan (hospitality), kesiapan, dan kesanggupan mengarahkan wisatawan. Yang perlu diperhatikan adalah kemampuan berbahasa petugas yang berada di lapangan masih rendah dengan nilai 15 (Tabel 2) karena bahasa yang dikuasai terbatas pada bahasa daerah setempat dan Bahasa Indonesia. Hal ini akan berpengaruh kepada pelayanan terhadap wisatawan yang berasal dari mancanegara, tentu menuntut kemampuan dalam berbahasa Inggris. Jika taman nasional ini dijadikan kawasan ekowisata diperlukan adanya peningkatan kapasitas petugas lapangan yang bersentuhan langsung dengan pelayanan wisatawan dengan pendidikan dan pelatihan untuk meningkatkan pelayanan.

Setiap wisatawan yang masuk untuk mengunjungi kawasan harus melakukan permohonan izin masuk kawasan kepada Kepala BBTNBKDS, akan menindaklanjutinya dengan menerbitkan Surat Ijin Masuk Kawasan Konservasi (SIMAKSI). Wisatawan akan dikenai tarif pungutan masuk kawasan konservasi sesuai dengan yang telah ditetapkan dalam Peraturan Pemerintah (PP) No. 12 Tahun 2014 Tentang Jenis dan Tarif Atas Penerimaan Negara Bukan Pajak pada Kementrian Kehutanan dan baru diperbolehkan memasuki kawasan jika SIMAKSI sudah diterbitkan.

\subsection{Akomodasi}

Suatu obyek wisata dapat dikembangkan dengan upaya: melakukan usaha promosi dan pemasaran, memperkecil kendala aksesibilitas melalui penyediaan sarana prasarana modal transportasi, meningkatkan pengelolaan dan pelayanan sesuai standar pelayanan, akomodasi (Karsudi et al., 2010). Semakin berkembang suatu kawasan wisata pasti akan menarik pembangunan baik sarana akomodasi maupun pemukiman baru, oleh karena itu pengembanganya harus dibatasi dan dijaga kelestarian lingkungannya (Wibowo dan Ma'rif, 2014).

Akomodasi merupakan salah satu kriteria yang diperlukan dalam kegiatan wisata, khususnya wisatawan dari tempat yang cukup jauh atau suatu yang disediakan untuk memenuhi kebutuhan, misalnya tempat menginap atau tempat tinggal sementara bagi orang yang berpergian. Penilaian terhadap kondisi terkini akomodasi tergolong rendah dengan nilai 30 (Tabel 2) dikarenakan keberadaan hotel, penginapan, dan losmen masih terpusat di Kota Putussibau. Sadap merupakan sebuah perkampungan kecil yang dihuni oleh etnik Dayak Iban dan merupakan pemukiman terdekat dengan kawasan TNBK. Masyarakat yang berada di desa Menua Sadap bersedia menjadikan rumah betang mereka sebagai homestay bagi wisatawan yang berkunjung, apalagi sejak ditetapkannya desa Menua Sadap termasuk salah satu dusun wisata di Kabupaten Kapuas Hulu pada tahun 2013 kemudian saat ini berganti menjadi desa wisata Sadap.

Salah satu alternatif adalah rumah masyarakat dijadikan sebagai tempat menginap (homestay) dengan memberikan keramahtamahan dan pelayanan bagi wisatawan. Beberapa anggota masyarakat telah menyiapkan biliknya untuk dijadikan sebagai "home stay" bagi tamu yang ingin menginap di Dusun Sadap. 
Sedangkan di kawasan bukit tekenang wisatawan dapat menginap di quest house tekenang yang mempunyai luas bangunan 292 meter persegi dengan bentuk bangunan semi permanent sebanyak 6 kamar. Jika homestay memiliki kualitas yang buruk dapat mengakibatkan berkurangnya wisatawan yang berkunjung ke kawasan tersebut, sehingga terjadilah penurunan jumlah wisatawan (Ahmad, 2013). Dengan tinggal di Homestay, wisatawan mendapatkan kesempatan untuk belajar mengenal alam, budaya masyarakat dan kehidupan sehari-hari di lokasi tersebut. Pihak wisatawan dan tuan rumah bisa saling mengenal dan belajar satu sama lain, dan dengan itu dapat menumbuhkan toleransi dan pemahaman yang lebih baik (Disbudar KH, 2014).

Homestay adalah sistem akomodasi yang sering dipakai dalam ekowisata. Peningkatan usaha home stay dengan cara melibatkan masyarakat sekitar, memberikan pelatihan dan pengarahan mengenai kebersihan dan kenyamanan suatu penginapan sehingga rumah masyarakat yang akan dijadikan home stay nyaman bagi pengunjung yang datang (Halumiaha et al., 2014). Homestay bisa mencakup berbagai jenis akomodasi dari penginapan sederhana yang dikelola secara langsung oleh keluarga sampai dengan menginap di rumah keluarga setempat (Disbudar KH, 2014). Ekowisata tidak menuntut akomodasi yang nyaman dan berfasilitas yang lengkap, akan tetapi memang sebaiknya jumlah homestay yang ada haruslah sesuai dengan kapasitas wisatawan yang berkunjung dan kebersihan lingkungan haruslah diperhatikan baik dari segi kebersihan dan keamanan.

\subsection{Sarana dan Prasarana Penunjang}

Dalam mendukung suatu pengembangan ekowisata, potensi atau daya tarik kawasan harus diikuti dengan pengembangan dan pengelolaan yang baik serta tersedianya sarana dan prasarana penunjang yang cukup, karena pada umumnya wisatawan tidak hanya datang untuk menikmati daya tarik saja tetapi juga ingin menikmati fasilitas yang mampu memberikan kepuasan. Sarana angkutan umum dari dan menuju lokasi dirasakan masih kurang baik dari segi kualitas maupun kuantitasnya. Wisatawan pada umumnya menggunakan kendaraan pribadi ataupun menyewa kendaraan dari travel untuk menuju ke kawasan dikarenakan masih kurangnya angkutan umum.

Pentingnya ketersediaan fasilitas yang baik untuk wisatawan dikarenakan adanya tingkat ketertarikan terhadap suatu destinasi dan akan dipengaruhi oleh ketersediaan fasilitas yang ditawarkan (Vengesayi, 2003). Kendala yang dihadapi dalam pengembangan sektor pariwisata adalah terbatasnya dana yang dialokasikan. Hal ini dapat berdampak pada terhambatnya upaya-upaya yang telah direncanakan terutama program-program peningkatan kuantitas dan kualitas prasarana, sarana berikut fasilitas penunjang kepariwisataan serta upaya-upaya pengembangan potensi wisata secara keseluruhan (BAPPEDA, 2010).

Suatu wilayah akan dapat berkembang jika tersedia sarana prasarana dan sosial untuk memenuhi kebutuhan penduduk. Semakin lengkap tersedianya prasarana dan sarana di suatu daerah maka akan semakin kuat daya tariknya untuk mengundang penduduk dan kegiatan produktif lainnya. Hal in menyebabkan suatu wilayah akan semakin berkembang (Adisasmita, 2008). Pengembangan sarana prasarana penunjang merupakan salah satu hal yang penting yang dapat memberikan kepuasan bagi wisatawan. Sarana prasarana penunjang harus disesuaikan berdasarkan selera pengunjung sehingga mampu memenuhi harapan penunjung. Pembangunan sarana prasarana harus tetap mengutamakan kealamian dan kelestarian lingkungan.

Hasil penilaian terhadap sarana dan prasarana penunjang kegiatan ekowisata di taman nasional ini dengan nilai 150 dengan klasifikasi tinggi (Tabel 2). Akan tetapi terdapat beberapa sarana dan prasarana yang perlu pembenahan dan evaluasi lebih lanjut keberadaan dan ketersediaannya untuk menunjang kegiatan ekowisata. Sarana penilaian menunjukkan kondisi sarana dan prasarana wisata, dimana kekurangan sarana dan prasarana ekowisata dapat memicu minat wisatawan yang rendah, oleh karena itu kondisi ini perlu diperhatikan dalam upaya pengembangan ekowisata. Dalam melakukan aktivitas ekowisata dan kegiatan penunjang lainnya fasilitas yang akan dikembangkan pada kawasan ekowisata haruslah disesuaikan dengan kebutuhan pengunjung.

\subsection{Ketersediaan Air Bersih}

Hasil penilaian air bersih tergolong tinggi dengan nilai 810, hampir semua lokasi tapak yang diamati tersedia air bersih sebagai sarana penunjang kegiatan wisata alam. Air bersih ini bisa diperoleh di Sungai Besar ataupun sungai-sungai kecil yang mudah ditemui di sekitar lokasi tapak. Namun untuk lokasi Gunung Betung dan Gua Pajau berada pada perbukitan yang tinggi sehingga jauh dari sumber air bersih. Kalaupun ada wisatawan yang datang berkunjung, harus membawa perbekalan air bersih dari sumber air bersih terdekat. Tidak adanya sumber air bersih juga menjadi pertimbangan untuk tidak dapat membangun sarana akomodasi di lokasi tersebut. Untuk kepentingan mengonsumsi, airnya perlu perlakuan sederhana, seperti dimasak terlebih dahulu dan disaring kemudian dapat diminum.

\subsection{Hubungan dengan Obyek Wisata di Sekitarnya}

Hasil penilaian hubungan dengan obyek wisata di sekitar kawasan tergolong tinggi. Pengembangan kawasan ini perlu memperhatikan keberadaan obyek 
wisata lain yang sejenis/tidak sejenis di sekitarnya sampai radius $50 \mathrm{~km}$, agar dapat dikemas sebagai suatu paket wisata sehingga saling menunjang kunjungan. Berdasarkan penilaian, hubungan dengan obyek wisata sekitarnya mendapat nilai 100 yang berarti tinggi (Tabel 2).

\subsection{Keamanan}

Hasil penilaian terhadap unsur dan sub unsur keamanan mempunyai nilai dengan klasifikasi tinggi yaitu 400 (Tabel 2). Kawasan ini cenderung aman dari binatang pengganggu, jarang gangguan keamanan dan ketertiban masyarakat, dan bebas dari kepercayaan yang mengganggu. Keamanan merupakan salah satu faktor yang menentukan dalam mendukung pengembangan obyek daya tarik dalam kegiatan ekowisata. Berdasarkan penelitian (Riyanto et al., 2014) bahwa suatu kawasan yang memiliki keamanan yang terjaga dan terjamin dari segala gangguan akan memberikan nilai yang positif bagi wisatawan dan membuat wisatawan merasa nyaman untuk beraktivitas.

Pembangunan pariwisata pada hakikatnya berbasis pada keamanan, artinya selama keamanan tidak terjamin, maka seluruh kreatifitas masyarakat di dalam pengembangkan potensi pariwisata akan terganggu (Pemanyun, 2010). Keamanan berkaitan dengan kenyamanan wisatawan dan kelestarian kawasan. Betapapun tinggi nilai obyek daya tarik, tetapi apabila kondisi keamanan tidak terjamin, maka wisatawan tidak akan tertarik untuk mengunjungi kawasan tersebut. Peningkatan kenyamanan dan keamanan pengunjung, pemberdayaan masyarakat serta perlunya kerjasama dengan pemerintah sangat diperlukan dalam pengembangan suatu kawasan.

\subsection{Rekapitulasi Penilaian Obyek dan Data Tarik Wisata Alam}

Potensi obyek wisata di taman nasional ini harus bisa dikembangkan secara bersama-sama apalagi sejak penggabungan pengelolaan kawasan taman nasional sejak tahun 2016. Pengelolaan dan pengembangan suatu kawasan konservasi untuk ekowisata perlu memperhatikan kelestarian obyek daya tarik wisata yang menjadi maskot dari kawasan tersebut. Kriteria penelitian yang dilakukan memiliki obyek daya tarik wisata, aksesibilitas, kondisi lingkungan masyarakat sosial ekonomi, pengelolaan dan pelayanan, akomodasi, sarana prasarana, ketersediaan air bersih, obyek wisata disekitar kawasan dan penilaian keamanan kawasan. Nilai tersebut menggambarkan bahwa potensi obyek dan atraksi wisata alam di taman nasional ini sangat baik untuk pengembangan ekowisata alam yang mengindikasikan bahwa kawasan ini memiliki potensi dan layak untuk dikembangkan sebagai destinasi ekowisata dengan indeks nilai potensi sebesar $78.20 \%$ (Tabel 2). Hal ini mengindikasikan bahwa secara umum kedua taman nasional ini memiliki potensi dan layak untuk dikembangkan sebagai destinasi ekowisata. Potensi ini memerlukan penanganan yang sebaik mungkin agar memiliki nilai dan berkontribusi bagi pembangunan daerah. Pemerintah daerah perlu memberikan perhatian yang lebih baik pada potensi ekowisata yang ada ini. Karena pengembangan wisata akan berdampak pada perkembangan sektor-sektor lainnya bila ditangani dengan baik.

Tabel 2. Rekapitulasi hasil penilaian potensi ODTWA

\begin{tabular}{|c|c|c|c|c|c|c|c|c|}
\hline No & Kriteria Penilaian & Bobot & $\begin{array}{l}\text { Nilai* } \\
\text { Total }\end{array}$ & $\begin{array}{c}\text { Nilai } \\
\text { Max** } \\
\text { Potensi } \\
\text { ODTWA }\end{array}$ & $\begin{array}{l}\text { Nilai } \\
\text { Potensi*** } \\
\text { (Skor total) }\end{array}$ & $\begin{array}{l}\text { Indeks } \\
\text { Nilai***** } \\
\text { Potensi } \\
(\%)\end{array}$ & $\begin{array}{c}\text { Klasifikasi } \\
\text { Potensi } \\
\text { ODTWA }\end{array}$ & Kelayakan \\
\hline 1 & Daya tarik obyek wisata & 6 & 840 & 900 & 5040 & 93.33 & Tinggi & $\begin{array}{l}\text { Layak } \\
\text { dikembangkan }\end{array}$ \\
\hline 2 & Kadar hubungan/aksesibilitas & 5 & 400 & 700 & 2000 & 57.14 & Sedang & $\begin{array}{l}\text { Belum layak } \\
\text { dikembangkan }\end{array}$ \\
\hline 3 & $\begin{array}{l}\text { Kondisi masyarakat sekitar } \\
\text { kawasan }\end{array}$ & 5 & 600 & 750 & 3000 & 80.00 & Tinggi & $\begin{array}{l}\text { Layak } \\
\text { dikembangkan }\end{array}$ \\
\hline 4 & Pengelolaan dan pelayanan & 4 & 280 & 360 & 1120 & 77.78 & Tinggi & $\begin{array}{l}\text { Layak } \\
\text { dikembangkan }\end{array}$ \\
\hline 5 & Akomodasi & 3 & 30 & 90 & 90 & 33.33 & Sedang & $\begin{array}{l}\text { Belum layak } \\
\text { dikembangkan }\end{array}$ \\
\hline 6 & $\begin{array}{l}\text { Sarana dan prasarana } \\
\text { penunjang }\end{array}$ & 3 & 150 & 180 & 450 & 83.33 & Tinggi & $\begin{array}{l}\text { Layak } \\
\text { dikembangkan }\end{array}$ \\
\hline 7 & Ketersediaan air bersih & 6 & 810 & 900 & 4860 & 90.00 & Tinggi & $\begin{array}{l}\text { Layak } \\
\text { dikembangkan }\end{array}$ \\
\hline 8 & $\begin{array}{l}\text { Hubungan dengan obyek } \\
\text { wisata }\end{array}$ & 1 & 100 & 100 & 100 & 100.00 & Tinggi & $\begin{array}{l}\text { Layak } \\
\text { dikembangkan }\end{array}$ \\
\hline 9 & Keamanan & 5 & 400 & 450 & 2000 & 88.89 & Tinggi & $\begin{array}{l}\text { Layak } \\
\text { dikembangkan }\end{array}$ \\
\hline & Jumlah & & 3610 & 4430 & 18660 & 78.20 & Tinggi & $\begin{array}{l}\text { Layak } \\
\text { dikembangkan }\end{array}$ \\
\hline
\end{tabular}


Keterangan :

* Hasil penilaian terhadap obyek dan daya tarik wisata

** Skor tertinggi untuk setiap kriteria

*** Perkalian antara bobot dengan nilai total

**** Indeks kelayakan : perbandingan nilai maksimal dengan skor tertinggi dalam persen

Semakin banyak potensi daya tarik wisata alam yang ada pada suatu kawasan akan semakin menarik minat wisatawan untuk berkunjung pada kawasan (Fandeli, 2000). Beberapa kriteria yang memiliki nilai sedang dan belum layak dikembangkan memerlukan perhatian dan pembenahan seperti aksesibilitas dan akomodasi, sehingga dapat menjadi prioritas jika kawasan taman nasional ini dikembangkan menjadi destinasi ekowisata. Pada prinsipnya ekowisata tidak terlalu memperhatikan akses yang sulit dijangkau maupun akomodasi yang terbatas karena jika dalam pengembangan ekowisata kawasan yang dijadikan lokasi berekowisata merupakan kawasan konservasi yang harus dijaga kondisi alamiahnya. Salah satu upaya pemanfaatan sumberdaya lokal yang optimal adalah dengan mengembangkan pariwisata dengan konsep ekowisata. Hal ini dapat menjadi pertimbangan Pemerintah Daerah Kabupaten Kapuas Hulu untuk mengoptimalkan potensi yang dimiliki untuk pengembangan pariwisata daerah ke depannya.

\section{Kesimpulan}

Kriteria penilaian yang dilakukan adalah obyek daya tarik wisata, aksesibilitas, kondisi lingkungan masyarakat sosial ekonomi, pengelolaan dan pelayanan, akomodasi, sarana prasarana, ketersediaan air bersih, obyek wisata disekitar kawasan dan penilaian keamanan kawasan. Berdasarkan kriteria ini rekapitulasi nilai potensi obyek dan atraksi wisata alam di TNBK dan TNDS bahwa kawasan ini layak untuk dikembangkan sebagai destinasi ekowisata dengan indeks nilai potensi kelayakan sebesar 78.20\%. Beberapa kriteria yang memiliki nilai sedang atau belum layak dikembangkan memerlukan perhatian dan pembenahan seperti aksesibilitas dan akomodasi, sehingga dapat menjadi prioritas jika kawasan taman nasional ini dikembangkan menjadi destinasi ekowisata. Potensi ini memerlukan penanganan yang sebaik mungkin agar memiliki nilai dan berkontribusi bagi pembangunan daerah.

\section{Daftar pustaka}

[1] [BAPPEDA] Badan Perencanaan dan Pembangunan Daerah. 2010. Rencana Pembangunan Jangka Menengah Daerah Kabupaten Kapuas Hulu 2011-1015. Kabupaten Kapuas Hulu, Bappeda.

[2] [BAPPEDA] Badan Perencanaan dan Pembangunan Daerah, 2015. Data Pokok Kabupaten Kapuas Hulu. Kapuas Hulu, Bappeda.
[3] [BBTNBK] Balai Besar Taman Nasional Betung Kerihun, 2015. Desain Tapak Pengelolaan Pariwisata Alam Lokasi Embaloh Sub Das Embaloh Taman Nasional Betung Kerihun. Kapuas Hulu, BBTNBK.

[4] [BTNDS] Balai Taman Nasional Danau Sentarum. 2009. Rencana Pengembangan Wisata Alam Taman Nasional Danau Sentarum. Kapuas Hulu, BTNDS.

[5] [BTNDS] Balai Taman Nasional Danau Sentarum, 2015. Desain Tapak Pengelolaan Pariwisata Alam Pada Zona Pemanfaatan Bukit Tekenang Taman Nasional Danau Sentarum. Kapuas Hulu, BTNDS.

[6] [BTNDS] Balai Taman Nasional Danau Sentarum. 2015a. Data Statistik Balai Taman Nasional Danau Sentarum Tahun 2014. Kapuas Hulu, BTNDS

[7] [Disbudpar] Dinas Kebudayaan dan Pariwisata, 2014. Roadmap Pengembangan Klaster Industri Ekowisata Kabupaten Kapuas Hulu, Kapuas Hulu.

[8] [DJPKA] Direktorat Jenderal Perlindungan dan Konservasi Alam, 2000. Penerapan Ekowisata dipandang dari Sudut Kebijakan Otonomi Daerah dan Konservasi Alam. Jakarta.

[9] [PP] Peraturan Pemerintah Republik Indonesia No. 12 Tahun 2014. 2014. Tentang Jenis dan Tarif atas Jenis Penerimaan Negara Bukan Pajak yang berlaku pada Kementerian Kehutanan.

[10] [PP] Peraturan Presiden No. 3 Tahun 2012. 2012. Tentang Rencana Tata Ruang Pulau Kalimantan. Jakarta: Sekretariat Negara

[11] Adisasmita, R., 2008. Pengembangan Wilayah. Yogyakarta, Graha Ilmu.

[12] Ahmad, A., 2013. Ecotourism in Brunei Darussalam: A Qualitative Evaluation of Its Sustainability. Journal of Environment and Human. 1(2), pp. 56-70.

[13] Beaumont, N., 2011. The third criterion of ecoturism: are ecotourism more concered about sustainability than other tourists. Journal of Ecotourism. 10(2), pp. 135-148.

[14] Eghenter, C., M. H. Putera, I. Ardiansyah, 2012. Masyarakat dan Konservasi 50 Kisah yang Menginspirasi dari WWF untuk Indonesia, WWF Indonesia.

[15] Fandeli, C., 2000. Pengertian dan Konsep Dasar Ekowisata. Yogyakarta, Fakultas Kehutanan UGM.

[16] Halumiaha, S., A.H. Dharmawan, E.I.K. Putri, 2014. Persepsi Masyarakat Lokal Terhadap Dampak Industri Pariwisata Taman Safari Indonesia ditinjau dari Konsep Pembangunan Berkelanjutan. Jurnal Pengelolaan Sumberdaya Alam dan Lingkungan. 4(2), pp. 126-135.

[17] Hoyman, M., J. R. McCall, 2013. Is there trouble in paradise? the perspective of Galapagos community leaders on managing economic development and environmental conservation through ecotourism policies and the special law of 1998. Journal of Ecotourism. 12(1), pp. 33-48.

[18] Karsudi, R. Soekmadi, H. Kartodihardjo, 2010. Strategi pengembangan ekowisata di Kabupaten Kepulauan Yapen Provinsi Papua. Artikel Ilmiah. Jurnal Manajemen Hutan Tropika XVI (3), pp. 148-154.

[19] Kasmiati, A. H. Darmawan, D. S. Bratakusumah, 2016. Ekowisata, Sistem Nafkah, dan Decoupling Sustainability di Wakatobi, Sulawesi Tenggara. Sodality: Jurnal Sosiologi Pedesaan 8(2016), pp. 158-164.

[20] Lochana, I.A., D. Soedharma, S. Sekartjakrarini, 2011. Perencanaan Pariwisata di Pulau Kera Kabupaten Kupang Provinsi Nusa Tenggara Timur. Jurnal Pengelolaan Sumberdaya Alam dan Lingkungan. I (1), pp. 31-37.

[21] Muganda M., A. Sirima, P.M. Ezra, 2013. The role of local communities in tourism development: grassroots perspective from Tanzania. Journal Human Ecology, 41(1):53-66. 
[22] Muhammad, F., 2012. Model Ekowisata Kawasan Hutan Mangrove Berbasis Daya Dukung Fisik Kawasan dan Resiliensi Ekologi. [disertasi]. Bogor.

[23] Ogechi, O.C., P.A. Igbojekwe, 2013. Local government and response to sustainable development in Nigeria: a study of local givernment authorities in IMO state. [Prosiding]. Intenational Conference on Tourism, Transport and Logistic, France.

[24] Pemayun, C.I.A., 2010. Format Kerjasama Pengelolaan Daya Tarik Wisata antara Pemerintah Kabupaten Gianyar dengan Desa Pakraman (Studi Kasus Pura Tirta Empul Tampaksiring, Pura Goa Gajah Bedulu dan Pura Dalem Padang. Tegal Ubud. Jurnal Analisis Pariwisata. 10(1), pp. 9-15.

[25] Purwanto, S., Syaufina L., Gunawan A., 2014. Kajian Potensi dan Daya Dukung Taman Wisata Alam Bukit Kelam untuk Strategi Pengembangan Ekowisata. Jurnal Pengelolaan Sumberdaya Alam dan Lingkungan. 4(2), pp. 119-125.

[26] Rahzen, T., 2000. Strategi Pengembangan Ekowisata Taman Nasional Bentuang Karimun. Prosiding Lokakarya Rencana Pengelolaan Taman Nasional Bentuang Karimun : Usaha Mengintegrasikan Konservasi Keanekaragaman Hayati dengan Pembangunan Provinsi Kalimantan Barat.

[27] Riyanto, Hamzari, Golar. 2014. Analisis Pembangunan Ekowisata di Kawasan Taman Hutan Raya Berbasis Sistem Informasi Geografis (Studi Kasus pada Blok Pembangunan
Wisata Ngata Baru Kabupaten Sigi). Jurnal Warta Rimba. 2(1), pp. 153-163.

[28] Rukti, D.T., I. Rudiarto, 2014. Potensi Pengembangan Ekowisata Berbasis Masyarakat di Kawasan Rawa Pening, Kabupaten Semarang. Jurnal Teknik PWK. 3(1), pp. 71-81.

[29] Sekartjakrarini, S., N.K. Legoh, 2004. Rencana Strategi Ekowisata Nasional. Jakarta Pusat. Kantor Menteri Negara Kebudayaan dan Pariwisata Indonesia, Jakarta.

[30] Shoo, R.A., A.N. Songorwa, 2013. Contribution of ecotourism to nature conservation and improvement of livelihoods around Amani nature reserve Tanzania. Journal of Ecotourism. 12(2), pp. 75-89.

[31] Suwantoro, G., 2004. Dasar-dasar Pariwisata. Yogyakarta, Andi Offset.

[32] Untari, R., 2009. Strategi Pengembangan Ekowisata Berbasis Masyarakat di Zona Wisata Bogor Kota Bogor. IPB, Bogor.

[33] Vengesayi, S., 2003. A conceptual model of tourism destination competitiveness and attractiveness. Anzmac: Conference proceedings; Des 1-3. Adelaide. Australia.

[34] Wibowo, P.A.S., S. Ma'rif, 2014. Alternatif Strategi Pengembangan Desa Rahtawu Sebagai Daya Tarik Wisata di Kabupaten Kudus. Jurnal Wilayah dan Lingkungan 2(3), pp. 245-256. 